Гарнага О. М. [1; ORCID ID: 0000-0002-5236-7299], к.е.н., доцент

${ }^{1}$ Національний університет водного господарства та природокористування, м. Рівне

\title{
ОСОБЛИВОСТІ УПРАВЛІННЯ ЗЕМЛЕКОРИСТУВАННЯМ
}

У статті розглянуто особливості управління землекористуванням, досліджено їх характеристику. Зазначено, що врахування перелічених особливостей зробить можливим адаптацію механізму управління збалансованим землекористуванням до умов сільськогосподарського виробництва. Проаналізовано підходи до економічної оцінки використання земель.

Ключові слова: земельні відносини; землекористування; господарська діяльність; ефективність; сільськогосподарські угіддя.

Вступ. Економічні трансформації, що відбуваються в Україні багато в чому визначають роль і значення управління землекористуванням. Це в більшості пов'язано з тим, що земля, крім iї традиційних властивостей (засіб виробництва, територіальний базис, природне утворення тощо), стала об'єктом правових відносин та об'єктом нерухомості. Аналіз проблем управління землекористуванням $€$ нагальною потребою сучасності, оскільки їх вирішення дозволяє встановити баланс між доступністю та попитом на земельні ресурси, якістю та економічною ефективністю. Ось чому дослідження особливостей управління землекористуванням $\epsilon$ надзвичайно актуальним питанням [1, С. 5].

Аналіз останніх досліджень і публікацій. Вагомий внесок у вивчення особливостей управління землекористуванням було здійснено: Д. Добряком, А. Даниленком, С. Булигіним, А. Крисак, В. Кулініч, В. Павловим, А. Мартином, А. Сохничем, А. Третяком та ін. Проте, беззаперечно визнаючи значний доробок вчених аграрників у дослідженні управління землекористуванням, варто відмітити, що низка проблем все таки потребує подальшого вивчення та опрацювання.

Постановка завдання. Мета дослідження полягає у вивченні особливостей управління землекористуванням.

Викладення основного матеріалу. Надзвичайно важливим завданням $€$ дослідження та розробка заходів з удосконалення 
системи управління землекористуванням, оскільки вони $€$ чи не найголовнішими в системі економічних відносин.

3 метою раціонального використання земельних ресурсів, успішного впровадження науково-обґрунтованих методів ефективного ведення господарської діяльності, створення сприятливих умов для відтворення родючого ґрунтового покриву, а також забезпечення необхідного комплексу заходів 3 охорони земель, що визначає зміст циклу управління, потрібно мати достовірну інформацію про землю, її продуктивність, природну якість та господарське використання, інформацію про сервітути та форми власності. Серед усієї сукупності категорій земельних ресурсів саме землям сільськогосподарського призначення притаманні специфічні ознаки і відповідний набір параметричних властивостей. Річ в тому, що землі, які використовуються в сільському господарстві різних зон, районів, господарюючих суб'єктів і навіть окремих ділянок, можуть мати специфічний набір просторових умов, які стосуються рельєфу, якості родючого ґрунтового покриву, рослинності, водного режиму, геологічної будови, а також інших природно-кліматичних ресурсів. Крім того, важливе значення мають і організаційно-економічні особливості використання земель, які зумовлені тим, що земельні ресурси в сільському господарстві виступають як засіб виробництва. Отже, такі властивості землі, як форма реалізації у сфері підприємництва, стан і набір споживчих якостей в процесі використання, оборотоздатність та інші, безпосередньо чинять вплив на ефективність використання і вартість земельного потенціалу.

Через вагомий вплив перерахованих параметричних властивостей на результат управління нами проведено виділення основних особливостей і здійснено опис їх специфіки стосовно управління землекористуванням, яке включає в себе їх організаційно-правові, господарсько-економічні та природноекологічні аспекти (таблиця).

3 погляду окреслених завдань особливості управління збалансованим землекористуванням у сільськогосподарському виробництві полягають в наступному:

- взаємозв'язок предметної та інформаційної областей досліджень взаємодії природи і соціуму характеризують результати управлінської діяльності;

- землекористування характеризуються значною кількістю різних ознак, без яких неможливе його сприйняття як цілісної природно-господарської системи;

- земельні ресурси характеризуються чітко визначеною просторовою приналежністю до тієі чи іншої території та 
господарюючого суб'єкта;

- специфічність управління та регулювання земельних ресурсів $€$ базисом для сталого територіального розвитку;

- в якості обмежень діяльності суб'єктів сільського господарства можуть виступати інституціональні фактори в сфері землекористування.

Таблиця

Характеристика особливостей управління землекористуванням

\begin{tabular}{|c|c|c|}
\hline $\begin{array}{l}\text { № } \\
3 / \pi\end{array}$ & $\begin{array}{c}\text { Параметри, що } \\
\text { характеризують } \\
\text { використання } \\
\text { земельних ресурсів }\end{array}$ & $\begin{array}{c}\text { Особливості земель сільськогосподарського } \\
\text { призначення }\end{array}$ \\
\hline 1 & Призначення & $\begin{array}{c}\text { Багатофункціональне екологічне, соціальне та } \\
\text { економічне. Засіб виробництва, предмет праці } \\
\text { та просторовий базис агробізнесу }\end{array}$ \\
\hline 2 & $\begin{array}{c}\text { Форма функціонування у } \\
\text { сфері підприємництва }\end{array}$ & Натурально-речова та вартісна \\
\hline 3 & Походження & $\begin{array}{c}\text { Частково відтворювальні, природний } \\
\text { компонент навколишнього середовища, } \\
\text { базовий ресурс споживчих благ, існує } \\
\text { незалежно від волі людини }\end{array}$ \\
\hline 4 & Ступінь рухомості & $\begin{array}{c}\text { Абсолютно нерухомі. Велика залежність } \\
\text { вартості від місця розміщення }\end{array}$ \\
\hline 5 & $\begin{array}{c}\text { Тривалість } \\
\text { господарського обороту }\end{array}$ & $\begin{array}{c}\text { Нескінченний цикл макроекономічного } \\
\text { відтворення }\end{array}$ \\
\hline 6 & $\begin{array}{c}\text { Стан споживчої форми в } \\
\text { процесі використання }\end{array}$ & $\begin{array}{c}\text { Зберігається натуральна форма протягом } \\
\text { усього періоду використання і простоювання }\end{array}$ \\
\hline 7 & $\begin{array}{l}\text { Знос в процесі } \\
\text { використання }\end{array}$ & $\begin{array}{c}\text { При раціональному використанні не руйнується } \\
\text { і не втрачає своїх корисних властивостей. У той } \\
\text { же час мають тенденцію до деградації та } \\
\text { погіршення якості ґрунтового покриву }\end{array}$ \\
\hline 8 & Зміна вартості за часом & $\begin{array}{c}\text { Потенційно вартість не знижується, а } \\
\text { підвищується через зростаючий їх дефіцит, } \\
\text { інфляцію та інші фактори } \\
\end{array}$ \\
\hline 9 & Кількість & Постійна \\
\hline 10 & Взаємозамінність & Не може бути замінена ніяким іншим ресурсом \\
\hline 11 & Якість & $\begin{array}{c}\text { Визначається місцем розташування, } \\
\text { ландшафтними особливостями і родючістю. } \\
\text { Здатні відновлюватися природним шляхом }\end{array}$ \\
\hline 12 & $\begin{array}{c}\text { Оборотоздатність на } \\
\text { ринку }\end{array}$ & $\begin{array}{c}\text { Окремі види земель обмежені або виключені } 3 \\
\text { господарського обороту }\end{array}$ \\
\hline 13 & Можливість сервітуту & $\begin{array}{c}\text { Право обмеження видів використання } \\
\text { земельних ділянок }\end{array}$ \\
\hline 14 & $\begin{array}{c}\text { Формування споживчої } \\
\text { вартості }\end{array}$ & $\begin{array}{c}\text { Здійснюється природними силами протягом } \\
\text { тисячоліть, а також в результаті уречевлення } \\
\text { суспільної праці в процесі } \\
\text { сільськогосподарського виробництва }\end{array}$ \\
\hline
\end{tabular}


Перераховані особливості роблять можливим адаптацію механізму управління збалансованим землекористуванням до умов сільськогосподарського виробництва.

В економічній літературі неодноразово розглядалися різні підходи до економічної оцінки використання земель. Були спроби знайти узагальнюючий показник (індексний), який давав би можливість одночасно визначити економічну ефективність використання землі та рівень розвитку господарства в цілому. Однак найчастіше ці показники носили досить умовний характер, практично не даючи жодного уявлення про ступінь використання землі, матеріальних і трудових ресурсів. У багатьох випадках пропонувалося оцінити економічну ефективність використання землі за показниками: валового доходу, чистого доходу, прибутку на одиницю земельної площі, валової продукції в грошовому вираженні та іншими показниками. Але так як продуктивні властивості землі приводяться в дію живою і уречевленою працею та проявляються в вироблених продуктах, то пряме розчленовування результату за факторами виробництва практично неможливе, бо сам процес виробництва здійснюється лише за наявності всієї їх сукупності, в конкретно здійснених пропорціях. Тому часто для всебічної оцінки використання землі застосовують систему окремих показників.

Найбільш поширеною $\epsilon$ система факторіальних і результативних показників.

Так, факторіальні показники можуть включати в себе їх структурні та ресурсні значення.

Структурні показники характеризують:

1. Рівень освоєння території:

$$
\text { Росв }=\frac{\text { Pс.2. }+ \text { Pnр.3. }}{\text { Рзаг }} \times 100 \%,
$$

де Росв - рівень освоєності території, \%; РС.г. - площа сільськогосподарських угідь, га; Рпр.з - площа присадибних земель, га; Рзаг - загальна площа господарства, га.

2. Рівень розораності сільськогосподарських угідь:

$$
\text { Рpсг }=\frac{P p+\text { Pб.н. }+ \text { Pnp.з. }}{\text { Pc.y. }} \times 100 \%,
$$

де Ррсг - ступінь розораності сільгоспугідь, \%; Рp - площа ріллі, га; Рб.н. - площа багаторічних насаджень, га; Рпр.з. - площа присадибних земель, га; Рс.у. - площа сільськогосподарських угідь, га.

3. Повнота використання здатних до оранки земель, що вказує на ступінь залучення в сільськогосподарський оборот: 


$$
K n=\frac{P p}{\text { Pnp.o. }},
$$

де Кп - коефіцієнт повноти використання придатних до оранки земель; Рp - площа ріллі, га; Рпр.о. - площа придатних до оранки земель, га.

4. Цільове використання земель:

$$
\text { Ки.в. }=\frac{\text { Pc.y. }}{\text { Pсг.np. }}
$$

де Кц.в. - коефіцієнт цільового використання земель; Рс.у. - площа сільськогосподарських угідь, га; Рсг.пр. - площа земель сільськогосподарського призначення, га.

5. Інтенсивність використання сільськогосподарських угідь:

$$
\text { Ki.в. }=\frac{P p+\text { Pб.н. }}{\text { Pс.y. }}
$$

де Кі.в. - коефіцієнт інтенсивного використання сільськогосподарських угідь; Рp - площа ріллі, га; Рб.н. - площа багаторічних насаджень, га; Pс.у. - площа сільськогосподарських угідь, га.

6. Технологічна роздробленість землекористування або землеволодіння:

$$
K m . p .=\frac{P p . \partial .}{P M},
$$

де Кт.р. - коефіцієнт технологічної роздробленості території; Рр.д. середня площа робочої (окремо оброблюваного) ділянки, га; $P$ M середня площа орного масиву, га.

У цю групу показників може бути включено і безліч інших: складність ґрунтової структури, лісистість території, напруженість рельєфу тощо.

Як правило, наведені показники обчислюються в динаміці та порівнюються між собою.

Ресурсні показники включають:

1. Наявність основних фондів сільськогосподарського призначення на 1 га сільськогосподарських угідь або ріллі:

$$
\Phi \epsilon=\frac{\Phi о c н}{P c . y .} \text { або } \frac{\Phi о c н}{P p},
$$

де Фє - фондоємність; Фосн - сума основних фондів сільськогосподарського призначення в грошовому виразі; Рc.у. або Рp - площі сільськогосподарських угідь або ріллі, га.

2. Наявність енергетичних потужностей на 1 га сільгоспугідь або ріллі: 


$$
E_{3}=\frac{M_{3}}{P c . y .} \text { або } \frac{M_{3}}{P p},
$$

де Ез - енергозабезпеченість 1 га сільгоспугідь і ріллі; Мз - всі енергетичні потужності у господарстві.

3. Виробничі витрати на 1 га ріллі або сільгоспугідь:

$$
\text { Ввга }=\frac{\sum B в}{P c . y .} \text { або } \frac{\sum B в}{P p},
$$

де $B B_{\text {га }}$ - виробничі витрати на 1 га; Вв - всього виробничих витрат; Рс.у. (р) - площа сільгоспугідь або ріллі, га.

4. Трудові витрати на 1 га ріллі або сільгоспугідь:

$$
T_{z a}=\frac{\sum T}{P c . y .} \text { або } \frac{\sum T}{P p},
$$

де $T_{\text {га }}$ - витрати праці на 1 га; $T$ - всього трудових витрат; Pс.у. (р) площа сільгоспугідь або ріллі, га.

Факторіальні показники, що відображають зміни в структурі земельних угідь і капітальних вкладень, дозволяють характеризувати ступінь раціональності та інтенсивності використання земельних ресурсів, а також розробити комплекс заходів щодо збільшення обсягів сільськогосподарської продукції [2].

Для більш повної і всебічної оцінки ефективності використання земельних ресурсів доцільно також використовувати результативні показники, до числа яких повинні входити:

- натуральні показники, що характеризують вихід продукції в натуральному вираженні на одиницю земельної площі, а також приріст продукції за певний період на одиницю площі;

- вартісні показники, до складу яких входять вартість валової продукції з 1 га землі, на 1 грн основних фондів, собівартість 1 ц продукції, вихід валового і чистого доходу на 1 га сільгоспугідь та ін.

Аналіз матеріалів та спеціальної літератури дає підставу зробити висновок, що причина нестійкості вибору критеріїв ефективності використання землі полягає в зміщенні факторіальних і результативних показників [3].

Слід зазначити, що факторіальні показники впливають на результативні, і навпаки. Крім того, показники раціональності та ефективності використання землі не тотожні, однак перші суттєво впливають на ефективність використання землі.

Висновки. Отже, врахування наведених особливостей зробить можливим адаптацію механізму управління землекористуванням до умов сільськогосподарського виробництва. А використання у розрахунках перелічених вище показників дасть можливість 
дослідити рівень ефективності використання земельних ресурсів, вони можуть бути застосовані для порівняння господарської діяльності всіх категорій господарств.

1. Гарнага О. М. Основи управління землекористуванням : монографія. Рівне : НУВГП, 2014. 212 с. 2. Кулініч В. В. Методологічна сутність еколого-економічної збалансованості природно-ресурсних систем. Землевпорядний вісник. 2002. № 1. С. 7-15. 3. Осипчук С. О. Сільськогосподарське землекористування України (сутність, проблеми, напрями вдосконалення). Землеустрій і кадастр. 2005. № 3. C. 51-71.

\title{
REFERENCES:
}

1. Harnaha O. M. Osnovy upravlinnia zemlekorystuvanniam : monohrafiia. Rivne : NUVHP, 2014. 212 s. 2. Kulinich V. V. Metodolohichna sutnist ekoloho-ekonomichnoi zbalansovanosti pryrodno-resursnykh system. Zemlevporiadnyi visnyk. 2002. № 1. S. 7-15. 3. Osypchuk S. 0. Silskohospodarske zemlekorystuvannia Ukrainy (sutnist, problemy, napriamy vdoskonalennia). Zemleustrii i kadastr. 2005. № 3. S. 51-71.

\author{
Harnaha O. M. [1; ORCID ID: 0000-0002-5236-7299], \\ Candidate of Economics (Ph.D.), Associate Professor
}

${ }^{1}$ National University of Water and Environmental Engineering, Rivne

\section{FEATURES OF LAND USE MANAGEMENT}

Analysis of land management problems is an urgent need of today, as their solution allows to establish a balance between availability and demand for land resources, quality and cost-effectiveness. That is why the study of the peculiarities of land use management is an extremely important issue.

The article considers the features of land use management, their characteristics are investigated. It is noted that taking into account these features will make it possible to adapt the management mechanism of balanced land use to the conditions of agricultural production. Approaches to economic assessment of land use are analyzed.

Different approaches to economic evaluation of land use have been repeatedly considered in the economic literature. There were attempts to find a generalized indicator (index), which would make it possible to simultaneously determine the economic efficiency of land use and the level of economic development as a whole. However, most often these indicators were quite conditional, giving almost no idea of the degree of land use, material and labor resources. Therefore, a system of individual indicators is often used to comprehensively assess land use. The most common is a system of factorial and performance indicators. 
Factorial indicators that reflect changes in the structure of land and capital investment, allow to characterize the degree of rationality and intensity of land use, as well as to develop a set of measures to increase agricultural production. For a more complete and comprehensive assessment of the efficiency of land use, it is also advisable to use performance indicators.

The analysis of materials and special literature gives grounds to conclude that the reason for the instability of the choice of criteria for land use efficiency is the shift of factorial and performance indicators.

It should be noted that factorial indicators affect performance, and vice versa. In addition, indicators of rationality and efficiency of land use are not identical, but the former significantly affect the efficiency of land use.

Using the above indicators in the calculations will make it possible to investigate the level of efficiency of land use, they can be used to compare the economic activities of all categories of farms.

Keywords: land relations; land use; economic activity; efficiency; agricultural lands.

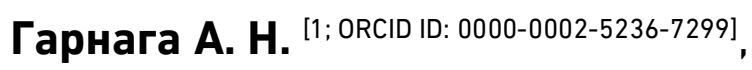
к.э.н., доцент

${ }^{1}$ Национальный университет водного хозяйства и природопользования, г. Ровно

\section{ОСОБЕННОСТИ УПРАВЛЕНИЯ ЗЕМЛЕПОЛЬЗОВАНИЕМ}

В статье рассмотрены особенности управления землепользованием, исследовано их характеристику. Указано, что учет перечисленных особенностей сделает возможным адаптацию механизма управления сбалансированным землепользованием к условиям сельскохозяйственного производства. Проанализированы подходы к экономической оценке использования земель.

Ключевые слова: земельные отношения; землепользование; хозяйственная деятельность; эффективность; сельскохозяйственные угодья. 